\title{
Eğitim ve Bilim Bağlamında Felsefi Bilincin Isşlevi
}

\author{
Murat BAHADIR \\ Erzurum Teknik Üniversitesi \\ E-mail: murat.bahadir@erzurum.edu.tr
}

\begin{abstract}
$\ddot{O}_{z e t}$
Bütün düşünme biçimlerinin varlık şartı olan felsefe, bir taraftan zihniyet ve bilinç meselesiyken diğer taraftan bilim ile eğitimin üzerine inşa edileceği/edilmesi gereken bir temeldir. Bu bağlamda ortaya konacak felsefe anlayışl, felsefenin temellendirici ve bütünleyici oluşundan dolayı bilim ve eğitimi belirlemektedir. Felsefe tarihi bu düşünceyi kanitlayıcı örneklerle doludur.

Toplumsal ve tarihi olgulara dayall olarak belli bir kültür çevresindeki mana ve içerik doğrultusunda belirlenen felsefe, evrenseli kucaklama çabasıldr. Bu anlayış çerçevesinde sorunlar ile yüzleşen ve felsefi nitelik taşıyan sorular ortaya konulmaldir. Bu da bireyin merak, şüphe, eleştirebilme ve soru sorma yeteneği ve cesaretine bağlldır. Felsefe, sorunsallaştıran, bu soru(n) üzerine düşünen ve çılkş yolları arayan kişinin etkinliğidir ki düşünmek sıkıntılı bir iştir. Ancak bu soru sorma eylemi toplumun yerel kaynaklarından beslenmelidir. Çünkü felsefe, kültürel ortamdan bağımsız olarak gelişemez. Bu bağlamda nitelikli felsefi bir sorusu olanın bilim ve eğitim anlayışıın şekillendirecek nitelikli bir felsefesi olacaktrr.

Kitle iletişim ve teknolojilerin sunmuş olduğu kolayliklar insanı düşünme ya da bir sorunu kendisine dert edinme ihtiyacından koparmaktadır. Hemen hemen her şeyin insana hazır sunulduğu dünyada düşünmenin/düşüncenin imkânı sallantıll ve sorgulanır hale gelmiştir. Özgün ve özgür düşünce üretmenin gittikçe zorlaştığı günümüz dünyasında düşünmek, sunulanı sorgulamadan kabul ve taklit etme olarak değerlendirilmektedir. Modern insan "bana uyar", "nasll dersen", "sen karar ver", "bence de" gibi ifadeler ile günü birlik hayatın devam ettirerek düşünmekten olabildiğince kaçınmaktadır. Bu bireylerden oluşan toplumların istikballerinin temeli olacak eğitim ve bilimi üretecek bir felsefe ve düşünceyi nasl ortaya koyacaktır? Çiftçisinden akademisyenine kadar herkesin kendi meslekleri, görevleri, rolleri çerçevesinde yüksek bir bilince sahip bireylerden oluşan bir toplum böylesi bir felsefi bilince nasıl sahip olacaktır? Bu bağlamda bilim ve eğitimin temeli olabilecek felsefenin işi hem zorlaşmakta hem de önemi artmaktadır.
\end{abstract}

Anahtar Kelimeler: Bilim, düşünme, eğitim, felsefe, felsefi bilinç

\section{Philosophical Awareness in the Sense of Education and Science}

\begin{abstract}
Philosophy, which is a must of all ways of thinking, is not only mentality and awareness matter but also a fundament where education and science can be built on. Philosophy sense which is to be put forward in this sense determines education and science as it is supplemental and determinant. History of philosophy is full of examples to prove this idea.

Philosophy which is determined in the light of meaning around the culture that dates back to social and historical facts is an effort to embrace the universal. In this sense questions that bear qualification of philosophy should be put forward. This is bound to person's curiosity, doubt, courage and ability to ask questions. Thinking is a troublesome work and philosophy is the work of a person who thinks upon this problem. But the act of asking questions should be supplied of local resources as philosophy cannot be developed independently from the cultural environment. In this sense, a person with noteworthy questions will have a noteworthy philosophy.
\end{abstract}


Convenience that mass media and technology offers pulls apart people from thinking of a problem. In the world where nearly everything is offered ready, thinking has become questioned. In today's world where it is becoming hard to produce unique and free thinking, thinking has been evaluated as accepting and imitating the offered. Modern people abstain from thinking by using statements like 'you decide', 'as you say', 'I agree' and they lead their daily lives. How can a society that is formed with those individuals introduce a philosophy and thinking? In this sense, the work and importance of philosophy which can be the fundament of education and science is getting harder.

Keywords: Education, philosophy, philosophical awareness, science, thought

\section{Giriş}

Başlangıçta akademik bir uğraş olmaktan ziyade bir yaşam biçimi olarak ortaya çıkan felsefe, son yüzyıllarda uygulamadan yoksun, yaşamdan kopuk kuramsal bir uğraş haline getirilmiştir (Marinoff, 2007: 20). Ancak felsefe sadece kuramsal bir uğraş olmaktan ziyade kuramsalın dışında olaylara dayalı savlar, önermeler ileri sürerek yapılan bir düşünme faaliyetidir de (Duralı, 2009: 82). Çünkü felsefe var olana ve olaylara karşı kayıtsız kalamayanların etkinliğidir (Gündoğan, 1993: 43). Kavramın kökenine indiğimizde bu durum daha açık bir şekilde ortaya çıkmaktadır. Philo ve sophia sözcüklerinden oluşan felsefe, sophia sözcügünün soyut bilgi anlamının yanı sıra akıllıca davranmak, aşırılıktan kaçınmak, kendine egemen olmak ve kötü durumlara göğüs germeyi bilmek anlamlarını da içermektedir. Dolayısıyla felsefe sadece bilgi elde etmek anlamında değil, doğru şekilde davranıp ahlaklı bir şekilde yaşayabilmek anlamında da kullanılmıştır ki Sokrates örneğinde olduğu gibi bilmek ile yapmak arasında sıkı bir ilişki kurulmuştur (Hilav, 2014: 13). Felsefe insanın doğasında vardır. Bu doğası ile çevresine yönelen insan hem onu hem de kendisini bilme yetkinliğine ulaşacaktır (Bakır, 2014: 15-16).

Felsefede genel olarak kuramsal olanın daha önemli olduğuna inanılır ancak felsefelerin ortaya çıkmasına sebep olan süreçler gözlendiğinde felsefe tarihi somut olan şeylerden yola çıkmanın ne kadar önemli olduğu gösteren örnekler ile doludur (Çotuksöken, 2000: 80-81). ${ }^{3}$ Aynı doğrultuda Feuerbach ${ }^{4}$ aklın bir başlangıç olmadığını, dolayısıyla da deneyden felsefeye geçmenin zorunluluk olduğunu, bu şekilde gerçekleşmeyen felsefi etkinliğin düşüncesiz bir realite son bulacağını söyler (1991: 45). ${ }^{5} \mathrm{Bu}$ bağlamda felsefenin insanın günlük hayatta karşı karşıya kaldığı sorunları dert edinmesi ${ }^{6}$ ile birlikte açığa çıktığ 1 iddia edilebilir ki gündelik hayatta başımıza gelen veya gözlemlediğimiz herhangi bir durum karşısında düşünmeye başlamamız teorik bir zeminde düşünmeye başladığımızın kanıtıdır (Gülenç, 2015: 182).

\footnotetext{
${ }^{3}$ Platon, Rousseau, Marx gibi birçok filozof kendi yaşamış oldukları toplum ve çevrede yaşanan olayların etkisinde kalarak düşüncelerini ileri sürmüşleridir. Bu bağlamda yaşadıkları tarih ve kültürel çevreden bağımsız olarak anlaşılamayacak olan felsefe, bir toplumun felsefi bilincini oluşturma amacı ile kullanılırken içinde yetiştiği ortamdan bağımsız, saf bir düşünce olarak ele alınmamalıdır.

${ }^{4}$ Feuerbach'a göre "Nesnel olmayanı nesnel, anlaşılmayanı anlaşılır hale getirmek, yani yaşama zevki nesnelerinden birini düşünce nesnesi, bilgi nesnesi düzeyine yüceltmek felsefenin bir edimidir" (Feuerbach, 1991: 44).

5 "Bilinçlenme serüveni deneyle başlar" (Timuçin, 1991: 29).

${ }^{6}$ Genel olarak felsefe, Platon'a dayandırılarak hayret duygusu ${ }^{6}$ ile ortaya çıktığı ileri sürülmüştür. Bu iddianın yanı sıra Çin ve Hint bilgeliğinde olduğu gibi nefse hâkim olmak gibi farklı kaynakların da felsefenin doğuşunda etkili olduğu ileri sürülmüştür (Duralı, 2009: 80). Ancak felsefe, hayret ve şaşkınlıktan çok toplumun, insanlığın huzurunu bozan bir sorunu insani kaygılar ile kedine dert edinen bir bilincin ürünü olarak ortaya çıkmaktadır.
} 
Felsefe, bir bilinç olarak yaşamının her anının içerisindedir ve içinde yetiştiği toplum ve çevreden etkilenmektedir. Bu bakımdan felsefe, hayatın ayrılmaz bir parçası olduğu bilinci ile bir toplumda konumlanmalıdır. Bunun aksine felsefenin insan hayatına sonradan dâhil edilmesi, felsefenin şüphe ile karşılanmasına ve anlaşılmaz olarak değerlendirilmesine sebep olmaktadır. İnsan hayatına sonradan giren bu tarz bir felsefe, felsefenin sadece metafizik bir etkinlik olduğunun düşünülmesine sebep olmaktadır. Oysa felsefe aşkın bir evrenden haberler veren metafizik bir uğraş olmaktan ziyade eğitimden bilime insanın her türlü eyleminin üzerine düşünülüp sorgulandığ 1 bir etkinliktir (Solak, 2005: 16-17). Bundan dolayı da felsefe, insanın eğitim, sanat, bilim gibi her davranışı yönlendirecek bir bilinç/tutum ${ }^{7}$ olarak değerlendirilmelidir. Çünkü bilgi, esasında bir bilinç sorunudur ve herhangi bir bilgi ancak belli bir bilinç ile belli bir bilinç içinde değer taşımaktadır (Timuçin, 1991: 27).

\section{Felsefi bilinç}

Felsefi bilinç; kendisini "olay ve olgulara bütüncül bakabilme”, "eleştirel bir zihne sahip olma" ve "hoşgörünün gerekliliği bilincinde olma" şeklinde kendini belli eden (Öner, 1999: 41), edinilen bilgileri yetersiz bulan, endişe duyan ancak buna rağmen hep bir arayış içinde olan, eleştiren bir bilinçtir (Hilav, 2014: 14). Bu bağlamda sofistçe bir tavır olarak değerlendirilebilecek felsefi bilinç, insan ürünü olan hiçbir şeyin kesin ve değişmez olmadığının bilincinde olmaktır.

Uygur'un "Olaylar insanın gözünü açabilir. Gene de en uygunu, insanın olaylara gözünü açmasıdır." (1981: 22) ifadesinden hareketle "Bütün düşünme biçimlerinin varlık şartı" (Çevikbaş, 2010: 43) olarak değerlendirilebilecek felsefe, kimyasal bir reaksiyonu başlatan bir aktivatör gibi insanın eğitim ve bilim gibi eylemlerini şekillendiren bir bilinçtir (Uygur, 2012: 35). Bu bağlamda bir tür zihniyet ve bilinç meselesi olarak değerlendirebileceğimiz felsefe, bir yandan felsefenin tüm altyapısını içerirken diğer yandan da sonradan ortaya çıkabilecek söylemleri de kavrayabilme olanağına sahiptir (Öner, 1999: 40; Çotuksöken, 2000: 23).

Felsefe her anlamda toplumun gelişmesinde önemli rol oynar. Toplumların tarihine baktığımız zaman bu iddiayı kanıtlayan ve bu gerçekliğin bilincinde olan birçok örnekle karşılaşmak mümkündür. 17. yüzyılda Kâtip Çelebi'nin

"Ulu Osmanlı devletinin ilk çağlarından Sultan Süleyman Han zamanına gelinceye dek hikmet (Felsefe) ile şeriat ilimlerini uzlaştıran gerçek araştırıcıları ün almışlardı. Ebülfeth (Fâtih) Sultan Mehmed Han Medaris-i Semaniye'yi yaptırıp kanuna göre iş görülüp okutulsun diye vakfiyesinde yazmış ve Haşiye-i tecrîd (Osmanlı medreselerinin ilk kısmında okutulan bir kelam kitabının adı) ve Şerh-i mevâkıf (Osmanlı medreselerinde okutulan temek akaid ve fen kitaplarından birinin adı) derslerinin okutulmasını bildirmişti. Sonra gelenler bu dersler felsefiyâttır diye kaldırıp Hidâye ve Ekmel derslerini okutmayı akla uygun

\footnotetext{
7 "Felsefi tutumlar her şeyden önce, ileri sürülmüş önermelerin biçimsel mantığa ve deneye dayalı ölçüler çerçevesinde belgelenip denetlenmesi şeklinde görünen kayı henüz ilke haline gelmemiştir. Bu yüzden de felsefi tutumlar, kanıtlanmağa, eleştirilip denetlenmeğe yapıları gereği yapıları gereği ihtiyaç duymayan inanç sistemleri ile ve ayrıca bunlara bağlı olup gündelik hayat tecrübeleri tarafindan beslenen bilgelik/hikmet binaları ile çoğu kere iç içe gözükürler" (Duralı, 2009: 96).
} 
gördüler. Yalnız bunlarla yetinmek akla uygun olmadığı için ne felsefiyat kaldı, ne Hidaye kaldı, ne Ekmel. Bununla Osmanlı ülkesinde ilim pazarına kesat gelip bunları okutacak olanların kökü kurumaya yüz tuttu. Kimi kıyıda köşede Doğu - Anadolu'da yer yer kanuna göre ders gören öğrencilerin daha başlangıçta olanları İstanbul'a gelip büyük tafra satar oldular. Onları görüp kimi kabiliyetli olanlar zamanımızda hikmet öğrenmek istediler. Fakir de yoklama ve ders okutma sirasinda istidadı olan öğrencileri Sokrat'ın Eflatun'u heveslendirdiği gibi, varlıkların gerçeğini araştıran bilimi öğrenmeleri için heveslendirdim, bu risalede de öğüt ve hepsine nasihat osun diye bir kaç madde alıp söyledim. Tâ ki mutlak ilim adına olanı elden geldiğince öğrenmeye çalışsınlar, elbette bir yerde lâzım olur, zararı olmaz. Kötüleyip inkâr eylemeyenler. Zira bir şeyi inkâr o nesneden uzak ve yoksul kalmaya yol açar" (Çelebi, 1993: 9-10).

sözü bu iddiayı destekleyici niteliktedir.

Bilim için felsefenin temel/gerekli olduğunun diğer bir göstergesi de insan bilimle elde etmiş olduğu gücü yine bilimle kontrol edememesidir. İnsanın bu çıkmazı sorgulayıp/denetleyip bilimi doğru kullanmasına imkân sağlayacak olan şey felsefi bilinçtir (Öner, 1999: 33).

Felsefi bilincin nasıl bir rol oynayacağı ile ilgili Brehier de insanın en temel eylemlerinden olan bilgi üzerinden görüşlerini açıklamıştır. Ona göre bilgi genel olarak bazen insanın kendi içinde ilerlemesi bazen de insanın eşya üzerindeki gücünün artmasıdır (Brehier, 1966: 28). Sosyal bilimler ve pozitif bilimler olarak değerlendirilebilecek bu iki bilgi türü karşısında felsefe, dengeleyici işlevinin yanı sıra sosyal bilimlerin pozitif bilimlere anlam vermesi gerekliliğini göstermenin yanı sıra düşüncenin pozitif bilimlerin kötü alıșkanlıklarının içine saplanıp kalmasını engelleyici işlevi vardır (Brehier, 1966: 31). Dolayısıyla felsefe, bu iki bilgi arasındaki dengeyi sağlayan aktif bir bilinç konumundadır.

Gelişen bilim ve teknoloji bir taraftan yanlışları asgari düzeye indirgemeye, var olan sorunları çözmeye imkân sağlarken diğer taraftan da yeni yanlışlara/manipülasyonlara, sorunlara sebep olmuştur. ${ }^{8}$ Diğer bir ifade ile bilim ve teknolojinin sağladığı gücün hayatın tüm alanlarında kullanılması bir yandan faydalı sonuçlar doğururken diğer yandan da insanın aleyhine olacak uygulamalara sebep olmuştur. Bununla beraber ortaya çıkan başka bir tehlike de insanların bilim ve teknolojinin cazibesine kapılarak değerler dünyasını ihmal etmesidir. Bu tablo ile karşılaşmamak ve bilimin insani amaçlara hizmet etmesini sağlamak için bilimin

\footnotetext{
${ }^{8}$ Bugün bilim ve teknolojiyi veya belli bir gelişmişlik seviyesinde olan ülkelerin sistemlerini en iyi ve kesin doğru olarak kabul edip sorgulamamak pozitivist bir anlayışın ürünüdür. Oysa bilimi, teknolojiyi ve sistemleri üreten ülkelerin ürünlerine o kadar da güvenmemiz gerektiği ile ilgili birçok örnek günümüzde yaşanmaktadır. Yakın zamanda ortaya çıkan Volkswagen'in emisyon skandalı bunun en güncel örneğidir. Buradan hareketle ileri sürebiliriz ki, bilim ve teknoloji bir taraftan kesin, güvenilir bilgiler sunarken bir taraftan da aldatıcı, manipüle edici bilgiler de sunmaktadır. İște bu noktada takınılması gereken tavır bu skandalı ortaya çıkaran, verilere güvenmeyip tekrar inceleme gereği duyan bir bilince sahip olmaktır. Bu da ancak felsefenin temel olacağı bir eğitim anlayışı ile mümkün olacaktır.
} 
insani değerler ile kontrol edilmesi gerekmektedir. Bu da ancak felsefi bilinç ile insanın bir bütün olarak ele alınması ile mümkün olacaktır (Öner, 1999: 34-35).

Böylesi bir felsefi bilince sahip olmak eleştirme, sorgulama gibi etkinliklerin yanında insan olmak -insani değerlerin, yaşamın, ölümün bilincinde olarak gerçekleştirilecekçıkar, kâr uğruna diğer insan dâhil tüm canlıları tehlikeye atacak bencilce eylemleri önleme açısından önemlidir. Russell'ın da dile getirdiği gibi insan eyleminin, özelde de eğitim ve bilimin tek amacı yararlılık değildir. Dolayısıyla eğitim ve bilim yalnızca fayda sağlayan, maddi şeyler üreten bir etkinlikten ziyade zihinsel zevklere de önem veren bireylerin daha insani niteliklere sahip olmasını sağlayan birer felsefi bilinç aracıdırlar. Eğer eğitim ve bilimi nasıl ve ne amaçla kullanıldığından ziyade sadece fayda sağlayan, sorunları çözen bir etkinlik olarak görürsek eğitim ve bilim ile boş zaman sağlamanın, birçok alanda gelişmeler sağlamanın ne anlamı olacaktır? (Russell, 2001: 18-20).

\section{Felsefi bilincin işlevi}

Felsefe bütünleştirici bir varoluş etkinliğidir. Bundan dolayı felsefenin insan hayatında yer alıp almaması bir tercih olmaktan ziyade zorunluluktur. İnsanın burada yapabileceği tek tercih; kendi kültüründen hareketle bilinçli, disiplinli, mantıklı bir akıl yürütme ile kendi felsefesini oluşturmak veya başkalarının kendi kültürleri üzerine inşa etmiş oldukları felsefelerine -kendi kültürümüz açısından geçersiz hükümler, sloganlar, dilekler, şüpheler, korkular çöplüğü olan- tabi olmaktır (Rand, 2003: 13).

Felsefenin insan için doğal bir zorunluluk olmasına karşın toplumlar uygarlaştıkça tercihini ikinci seçenekten yana kullanmışlar veya kullanmak zorunda bırakılmışlardır. Bundan dolayı felsefenin en çok itibarını yitirdiği çağın yirminci yüzyıl olduğu ileri sürülebilir (Dural1, 2009: 77). Günümüzde akıl, dolayısıyla düşünme Horkheimer'ın de üzerinde durduğu gibi eleştirel olma özelliğini kaybetmiştir. -kitleselleşen toplumlardaki eleştirisellik daha çok bireysel bilinç ile eyleme dönüşmekten ziyade yönlendirilme ile eleştiriden ziyade anlayıp değerlendirmeden reddetme şeklinde vuku bulmaktadır-. Akıl, eleştiriselliğin özerkliğinden ziyade kişisel veya belli sistemlerin faydasına hizmet eder hale gelmiştir (Gülenç, 2015: 242). Bu durum da akıl, gerçekliğe direnemeyerek bir taraftan deneyime boyun eğmiş diğer taraftan da giderek insandan bağımsız bir süreç haline gelmiştir (Gülenç, 2015: 248). En son teknoloji ürünü kitle iletişim araçları, endüstrinin üretmiş olduğu araçlar ve modernitenin önermiş olduğu yaşam biçimi insanların kendi yaşamlarının dışında ailesini, toplumu, ülkeyi, dünyayı, ilgilendiren sorunları dert edinmesine engel olmaktadır. Felsefe, yerleşik toplumların uygarlaşma sürecindeki en insani ihtiyacı olmasına karşın, her şeyin hazır, paketler, kurlar halinde sunulduğu dünyada bir ihtiyaç olmaktan çıkarılmıştır (Duralı: 2009: 101). Bu da felsefenin insani bir ihtiyaçtan çok belli kesimlerin uğraştığı, anlaşılmaz, fayda vermeyen bir etkinlik olarak değerlendirilmesine sebep oluştur. Bu bağlamada ilk etapta felsefeden uzaklaşan bireyler, ikinci olarak istenilen şekilde yönlendirilen/manipüle edilebilen varlıklar haline gelmiştir.

Felsefenin imkânı için ya da düşünebilmek için şart olarak ileri sürülen zenginlik, boş zaman gibi unsurlar bugün bir şart olmaktan ziyade düşünme imkânını baltalayan engeller haline gelmiştir. Bu bağlamda felsefe, rahat insanın bir eylemi olmaktan 
ziyade sorunlar edinen, bunlar üzerine kafa yoran, s1kılan, hayat1 etkilenen, bugün ve gelecek için endişeleri, ümitleri, hayalleri olan bir insanın eylemidir. Bu bağlamda eğer insan kendisine düşen görevi yerine getirmezse Nermi Uygur'un dile getirdiği tablo ile karşılaşmak zorunda kalacaktır; "sen kapını kirletirsen başkaları çöplük yapar." (1981: 38).

Uygur'un ifade ettiği şekilde gelişmiş bir toplumda insanlar kendilerine sunulan seçenekleri yine kendisine sunulan yaşam şekli çerçevesinde tüketmek zorunda kalmaktadırlar. $\mathrm{Bu}$ şekilde beklemeye alıştırılan insan, düşünme melekelerini kullanamaz hale getirilmiştir. Oysaki düşünmek herkesin tecrübe ettiği yollardan başka yollarda yürüyebilme cesaretini gösterip kendi yolunu açabilmektir. Bundan dolayı da düşünmek sıkıntılı ve zor bir iştir. Bu sıkıntılı ve zor sürece dâhil olmak istemeyerek benim yerime bir başkası düşünsün tavrını gösterenler bu davranışlarının tüm sonuçlarına katlanmak zorundadırlar (Uygur, 1981: 19-20).

Günümüz toplumda bireyler, düşünmeye ve dolayısıyla çalışmaya karşı olumsuz bir tutum içerisindedirler ve bu tutum toplumun çeşitli anlatım türlerinde de kendine yer bulmaktadır. Bu bağlamda çalışmaktansa yan gelip yatmayı tercih eden Temel ile Temel'in bu tavrına kızan Dursun ile ilgili anlatılan fikra buna örnek olarak verilebilir. Dursun her gördüğü yerde çalıșmadığı için Temel'e kızar. Dursun'un bu kızgın tavırlarına ilk başlarda kayıtsız kalan Temel, en sonunda Dursun'a "neden çalışayım?" diye sorar. Temel'in iyiliğini isteyen Dursun, "eğer çalışırsan para kazanırsın, kazandığın parayla istediğin şeyleri alırsın, istediğin şeyleri alınca da rahat eder yan gelip yatarsın" cevabını verir. Dursun'un vermiş olduğu bu cevaplara burun kıvıran Temel ise "ben zaten yan gelip yatıyorum bunun için neden kendimi o kadar yorayım" cevabını verir. Temel'in vermiş olduğu cevap akıllıca, insanı güldürür cinstendir belki, ama burada gözden kaçırılmaması gereken ayrıntı vardır; Temel'in yatıp dinleneceği gölge kimin veya neyin gölgesi olacaktır? İnsanın çalışıp kendi üretmiş olduğu şeylerin gölgesinde yatması mı yoksa başkasının üretmiş olduğu şeylerin gölgesinde yatması $\mathrm{m} 1$ daha güvenli olacaktır? İşte bu noktada bireyin kendi kültüründen kaynaklanacak olan felsefi bilinç ile gerçekleştireceği eğitim ve bilim hem o bireye hem de o bireyin içinde yaşadığ 1 topluma fayda ve güven verici olacaktır. Bu amaç doğrultusunda insanın gününü değerlendirmesine ve geleceğini görebilmesine imkân veren felsefe, geçmişe ait zengin deneyimi göstererek, insanın kendi kaderini çizmesinde ona yardımcı olacaktadır. Diğer bir ifade ile felsefe insanın kendi düşünceleri, sözcük ve eylemleri ile oluşturduğu kültürel tarihi ile kendi doğasını uzlaştırmada önemli rol oynayacaktır (İbanez, 1998: 22). Çünkü insan tarih boyunca, ne bilgi, ne kendine güven, ne iç huzuru, ne de aklını doğru şekilde kullanma gibi hiçbir şeyi kendiliğinden hazır olarak elde etmemiştir. İnsan hayatını kolaylaştırmak ve bazı ihtiyaçlarını gidermek için keşfetmek ve öğrenmek zorundadır. İşte bu noktada felsefi bilinç ve dolaysıyla da bu bilinci sağlayacak olan felsefe eğitimi, insana yardımcı olacak ve gelişmesini sağlayacak özel bir entelektüel duruş kazandiracaktır (Rand, 2003: 16-17). Bu da Nietzsche'nin "Kendi tehlikesinin bilincine varan bir halk, dehayı yaratır" (Nietzsche, der nachlass, 1872'den aktaran Uygur, 2012: 22) sözünde ifade ettiği gibi bir toplumun kendi dinamiklerine uygun bir şekilde gelişmesini sağlayacaktır.

Bir felsefe sistemi, dayandığı bilim ve yaşantıdan hareketle insanı, toplumu, dünyayı anlamlı bir bütün olarak kavrama çabasıdır. Bu yüzden felsefi sistemin etkisi ile gelişen uygarlık her türlü unsuru ile bir düzenlilik gösterecektir. Bu çizgide ilerleyen 
felsefileşmiş medeniyetlerde yaşayan her birey de bu felsefi bilinç ile hareket edecektir (Duralı, 2009: 49-50). Bu bağlamda felsefe, bir meslek, genel kültür olmaktan ziyade insanın eğitim ve bilimsel faaliyetlerini şekillendiren bir yaşam biçimidir. Felsefenin, felsefe eğitiminin amacı da bu olmalıdır. Bu şekilde gerçekleştirilecek bir felsefe eğitimi, felsefenin bir yaşama biçimi haline gelmesine katkı sağlayacaktır. Ancak felsefenin yaşam şekli haline gelebilmesi için toplumdaki sorunlar dert edinen insanlara ihtiyaç vardır (Taşdelen, 2015: 151).

Felsefe ancak toplumdaki karşılığı keşfedildiğinde anlamlı hale gelecek, gerçeklik ve hakikat değeri taşıyacaktır. Felsefenin toplumdaki karşılığını aramayan bir felsefe eğitimi de eksik ve kusurlu bir eğilim olacaktır (Taşdelen, 2015: 18). Bu bağlamda felsefe tarihinde ele alınmış sorunlar önemlidir ancak felsefe, sadece geleneksel sorunlarla ilgilenmek değil, dönemin bilimsel, politik, ekonomik karakterine bağlı olarak toplumunu etkileyen sorunları felsefi gelenek çerçevesinde ele alabilmektir (Taşdelen, 2015: 26). Dolayısıyla yaşamış olduğu zamanı, mekânı anlamlandırabilen ve bunlarla ilişki kurabilen toplumların felsefi bilinçleri daha da gelişecektir. ${ }^{9}$ Her ne kadar bireysel olsa da içinde yaşadığı toplumdan beslenen felsefi bilinç, kendi sorunları üzerine düşünme cesaretinde bulunan bir toplumda gelişen bilinçtir (Taşdelen, 2015: 33). Bu yüzden farklı toplumlarda tartışılan felsefi sorunları yerine kendi sorunlarımızı fark edip felsefileştirmeliyiz. Çünkü "Felsefeci günün kültürünü yaşayan ve onun üzerinden bilinç geliştirmek durumunda olan düşünürdür" (Gürsoy, 2006: 37; İnam, 1993: 2).

Felsefi bir bilince sahip olmanın şartı, toplumun kendi tarihi ve kültürel değerlerinden hareket etmesidir. Çünkü hem felsefe hem de felsefi bilinç kültürel ortamdan bağımsız olarak gelişmez (Akdemir, 2004: 53). Diğer bir ifade ile işe yarar sağlıklı bir felsefi bilinç için her toplum kendi kültürel zeminini kullanılmalıdır. Bu doğrultuda hareket eden toplum, kendi öz kimliği hakkında açık bir bilince erişecektir. Ancak böyle bir bilinç ile hareket eden toplum kendi geçmişini anlamlandırabilecektir.

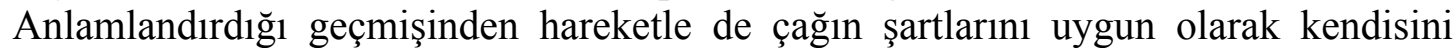
yeniden şekillendirecektir. Felsefi düşünce ile hareket eden toplum bu yeni yapıyı oluştururken daha güzel, daha düzgün değerleri bu yeni yapıya eklemlenmesi söz konusudur. Özetle eleştirici, düzeltici, bütünleyici olan felsefi düşünme yıkıcıllı̆ın panzehridir (Dural1, 2009: 105).

Eğitim ve bilim alanında amaçladığı özel hedeflere ulaşmak isteyen toplumların felsefi bilince sahip olması gerekir. Bu bilince sahip olmayan toplumlar, kendi felsefesini ve buna bağlı olarak eğitim ve bilim sistemlerini üretmek yerine başkalarının sistemlerini benimseyen, düşünme tembeli, korkağı bir toplum haline gelirler. Oysaki yaşanmış felsefeden yeni bir yaşam felsefesi çıkmamaktadır (Uygur, 1981: 5). Felsefe, kişinin kendi varoluşundan çıkardığ 1 soru ve cevaplarla yine kendi varoluşunda keşfedeceği bir etkinliktir. Zira felsefe toplumda karşılığı olan bir etkinliktir ve ancak bu şekilde anlamlıdır (Taşdelen, 2015: 150). Bunun yanı sıra toplum, kendisine ait olmayan bir şeyi kendisine aitmiş gibi görmeden, sorunlara başkaları gibi değil, ama onları da göz ardı etmeden kendi perspektifinden bakmanın olanağ1 üzerinde de düşünmelidir (Çevikbaş, 2010: 42). Bunu yaparken de "kendi geçmişinden başka bir endişesi olmayan her araştırma en sonunda kendini tüketir"

\footnotetext{
${ }^{9}$ Üzerinde düşüneceğimiz her şeyin hayat ile bütünleştirilebilmesi için düşünülecek şeyin kültür içinde bir anlamı karşıllı̆̆ olmalıdır. Bunun için de felsefe, yerel kültürel unsurlardan hareketle gerçekleştirilmelidir (Çevikbaş, 2010: 40 ).
} 
ilkesi göz önünde tutulmalıdır; çünkü araştırmanın canı bugündedir. ${ }^{10}$ Bundan dolayı her filozof en çok kendini ve içinde yaşadığı toplumu rahatsız eden bir sorunu dert edinerek $^{11}$ felsefileştirdiği sorunlar üzerine düşünmelidir (Uygur, 2001: 179). Çünkü felsefe, yaşayışımızdan kaynaklanmalı ve toplumsal zamana duyarlılık taşımalı yani felsefe, sicak olmalıdır (İnam, 1993: 7-10).

Toplum için bu kadar önemli olan felsefi bilinç ile sorunlara çözüm bulmayı L. Marinoff, Felsefe Terapisi adlı eserinde beş aşamada formülleştirerek açıklamıştır. Marinoff'a göre felsefi bilinç ile düşünmenin birinci aşaması "Problem"i yani sorunu teşhis edip onun farkına varabilmektir. Birinci aşamayı fark etmek felsefi bilinç için yeterli değildir. Toplumda herkes bazı sorunların olduğunu fark edebilir ancak herkes bu sorunu duygusal olarak dert edinip üzerine düşünmeyebilir. İşte bu noktada ikinci aşama devreye girmektedir; "Emotion" yani tespit edilen sorunu dert edinebilmek ve bu sorunlar karşısında rahatsızlık hissi duymak. İnsanın felsefi bilincinin harekete geçtiğinin en önemli göstergelerinden olan bu aşamadan sonraki aşama ise "Analysis" aşamasıdır. Bu aşama sorunun nasıl çözüleceği ile ilgili seçenekler aramak ve bunları değerlendirebilmektir. Dördüncü aşama ise "Contemplation" yani durumun bütünü, farklı boyutları hakkında derinlemesine düşünebilme süreçlerini kapsamaktadır. İşte bu aşama toplumun kendi kültürel alt yapısının dışında diğer toplumların geliştirmiş olduğu felsefelerin de gözden geçirilip değerlendirileceği aşamadır. Bu tavır felsefileştirdiğimiz sorunları farklı boyutları ile daha iyi anlamak adına gerçekleştirilen bir süreçtir. Beşinci aşama ise "Equilibrium" yani sorunun iç yüzünü kavrayıp uygun ve gerçekleştirilebilir bir şekilde harekete geçebilmektir. Tüm bu süreçler ile toplum yeniden dengeye ulaşacaktır (Marinoff, 2007: 55-57). Marinoff'un felsefi bilincin nasıl işleyeceği ile ilgili olarak ortaya koymuş olduğu bu açıklama aynı zamanda felsefi bilinç ile hareket eden bir toplumun bu beş aşamada ulaşacağı dengeyi de kapsayacak şekilde barış anlamına gelen "PEACE" kelimesinin yazılmasına imkân sağlayan simgesel bir anlatıma da sahiptir. Marinoff' un işleyişini belli aşamalara ayırmış olduğu felsefi bilinç ile sorunlara yaklaşmayı bir dedektif hikâyesindeki esrarengiz bir sorunu çözmek için yürütülen zihinsel faaliyette benzetmek mümkündür. Bu bağlamda felsefi bilinç niçin ve nasıl soruları ile kimin katil, kimin kahraman olduğunu anlamak için her yolu, her ipucunu ve emareyi izleyin bir süreçtir. Bu süreçte cevapları belki derhal bulamayacaksınız, fakat paha biçilmez bir özellik kazanacaksınız: esaslara göre düşünme yeteneği” (Rand, 2003: 16).

Her toplumun kendi şartlarına göre gelişmesine imkân sağlayacak olan felsefi bilinç ile ilgili olarak üzerinde durulması gereken bir diğer sorun ise felsefi bilinci taşıyacak olan aklın nasıl konumlandırılacağıdır. Diğer bir ifade ile aklın bir kılavuz mu yoksa kılavuza gereksinim duyan bir güç mü olduğu sorusudur. Pozitivist aydınlanmacı mantık anlayışıyla aklı bir kılavuz olarak kabul etmek mi yoksa Sokrates-Platon vari aklı doğru bilgiye ulaşmanın/mutlu/erdemli olmanın bir aracı olarak kabul etmek mi doğru bir yaklaşım olacaktır? Eğer akıl kılavuz olarak kabul edilecekse, hangi aklın veya nasıl bir aklın kılavuz olarak kabul edileceği, kılavuz olarak toplumlar kendi

\footnotetext{
10 "Felsefe, her ne kadar evrensel ethosuyla kendisini evrensel kültüre katsa da fillozoflardan kendi ortamlarının, kendi yaşantılarının izlerini taşıyacak ifadeler de bekleriz. Yapacakları felsefenin, onların kendi dil, kültür, gelenek ve yaşantı çevresinden türemesi gerektiğini de düşünürüz" (Taşdelen, 2015: 14).

${ }^{11}$ Feuerbach'ında ifade ettiği gibi "yürek başkaldırır, kafa reforme eder; kafa şeyleri yaratır, yürek harekete geçirir" (Feuerbach, 1991: 70).
} 
kültürlerinin gelişiminin bir sonucu olan kendi akıllarını mı yoksa farklı bir kültür çevresinde gelişen bir başkasının aklını mı tercih edeceği veya tercih etme hakkına sahip olup olmayacağı ile ilgili yeni sorular eklenmektedir.

Akıl ile ilgili yukarıda ifade edilen sorular dikkate alındığında bu konu tartışmalı bir hal alacaktır. Ancak yine de bu tartışmada aklı bir kılavuz değil toplumun kendi doğal kültürel gelişiminde şekillenen ve bu süreçte işlerken kılavuz olarak alacağ üreten potansiyel bir güç olarak değerlendirmek daha "makul" bir yaklaşım olacaktır. Çünkü aklı kılavuz olarak ilan etmek belli çıkarlar doğrultusunda ortaya konan bir akıl gerektirir. Dolayısıyla da kılavuz olması istenen akıl aslında belli bir amac1 gerçekleştirilen aklın araçsallığını saklamak için kullanılan bir perde görevi üstlenmiş olur. $\mathrm{Bu}$ "perde" mekanizmanın doğuracağı tehlikelerden veya bu mekanizmanın işleyen bir unsuru haline gelmekten kaçınmak için öncelikle felsefi bir bilince ${ }^{12}$ sahip olmaya imkân tanıyacak anlayışa önem veren bir eğitim anlayışının uygulamaya konması gerekmektedir. Bu anlayışın sonucu olarak felsefi bir bilince sahip olan kişi "toplum duygusu olan, çevresiyle iyi ilişkiler kurabilen, körü körüne başkasının peşinden sürüklenmeyen, kendi yolunu aklı ile bulmaya çalışan, hayatı kendi çabasının ürünü haline getirmeye çalışan, iyimser, umutlu, zorluk karşısında yılmayan, seçenekler arayan, hoşgörülü, hayatı katı sınırlara ayrılmamış, yanlışları doğruya yaklaştıran bir adım olarak gören kişi”" (Taşdelen, 2015: 141) hâline gelecektir.

\section{Sonuc}

Tarih boyunca olduğu gibi günümüzde de bireyler mutlu bir şekilde yaşaması, var olanı daha iyi tanıması ve eylemlerinin olumlu yönde gelişmesi için felsefi bilince sahip olmalıdırlar. ${ }^{13}$ Dolayısıyla eğitim her aşamasında Marinoff'un ifade ettiği süreçleri içeren veya bu süreçlere hizmet eden amaç ile gerçekleştirilmelidir (Öner, 1999: 258). Zira;

"Felsefe eğitimi, felsefe bilinci eğitiminden başka bir şey değildir. Felsefece yetişme; bu bilinci durmadan genişletmek; bu bilincin sağladığı bilgiler derlemek, bu bilincin ulaştığı derinlikle bilgeleşmektir. Felsefe eğitimi işte bu anlamda bir olgunluk kazandığı sürece anlamlı bir etkinliktir" (Uygur, 2012: 98).

Ancak yukarda ayrıntılı bir şekilde ifade etmeye çalıştığımız üzere "felsefe öğrenimi bir lüks, bir angarya olarak telakki edilmeyip, gerekliliği göz önüne alınarak ciddiyetle yapılmalıdır. Mühendislikten Edebiyata her fakülte ve yüksekokulda felsefe dersleri olmalıdır" (Öner, 1999: 36). Bu bağlamda herhangi bir eğitim kurumunda okuyan veya herhangi bir meslek ${ }^{14}$ dalıyla uğraşan kişi, okuduğu veya çalıştığı alan ile ilgili daha farklı, kolay, ekonomik, çevreci bir yol endişesi ile düşünce dünyasını

\footnotetext{
${ }^{12}$ Bir tefekkür sonucu hoşgörü duygusunu gibi her zihni faaliyeti kazandırmak felsefi bir tutumdur. Bu tutuma insanları bilinçli olarak vardırma felsefenin işidir (Öner, 1999: 23).

${ }^{13} \mathrm{Bu}$ bağlamda da Felsefe eğitiminden söz edilir edilmez akla gelen ilk şey felsefe bilinci olmalıdır (Uygur, 2012: 96; Öner, 2012: 21).

${ }^{14}$ Bugün gelinen noktada bir doktor felsefe ile ilgilenmelidir. Doktor olmanın gereği olan işleri yapmak bir kimseyi doktor olarak adlandırmak için yeterli değildir. Bunun için daha fazlası gerekir. İnsanın yaşamına, varlığına, gerek kendisinde gerekse öteki insanda yani hastada temel olana ilgisini yönetmesi, tıbbi hümanizma uygulaması gerekir (İbanez, 1998: 10).
} 
şekillendirebilecektir. İnsan sahip olduğu mesleğin imkânlarını insani çerçevede kullanma ve geliştirme imkânı bakımından bu çok önemlidir. Bu sebepten dolayı eğitim zorunlu olmaktan ziyade zorunlu olması gerektiği bilincinin yerleştirilmesi ile gerçekleştirilmesi gereken bir etkinlik olmalıdır. Russell'ın da ifade etiği gibi eğitimin itici gücü içten gelen bir öğrenme isteği, bilinci olmalıdır (Russell, 2001: 28). Bu da bilmenin sağlayacağı imkân ve bilginin bir yaşam biçimi olarak vurgulanması ile gerçekleştirilebilir.

Felsefeyi bir yaşam biçimi olarak hayatın her alanında işler hale getirmek bir ütopya olarak algılanmamalıdır. Amerika gibi uygar/gelişmiş olarak değerlendirilen toplumlarda felsefe/felsefi bilinç, günlük hayattın bir bileşeni olarak çeşitli alanlarda kullanılmaktadır. New York gibi birçok eyaletindeki hastaneler, doktorların herhangi bir hasta için hayat ya da ölüm kararı verirken danışıp görüşebilecekleri felsefeciler istihdam etmektedirler. New Hampshire eyalet hukukçularının ve Connecticut hapishane yetkililerinin danışıp görüşmeleri için, felsefeciler çalıştırılmaktadır. Felsefeciler, atom çekirdek atıklarının yok edilmesi ve genetik mühendisliği gibi meselelere eğilmektedirler. Senatörlere yardımcı olmak üzere, mecliste dört adet memur felsefecisi bulunmaktadır. İşte bu durum felsefenin temellendirici ve bütünleyici yanının ortaya çıkmasının, felsefenin yaşamla bütünleşmesinin yani felsefi bir bilincin sonucudur (Türker-Küyel, 1986: 67-68).

Sonuç olarak geleceğin eğitim ve bilimini şekillendirmek istiyorsak kültürel birikimimizi felsefi bir bakışla yeniden okuyup değerlendirmemiz gerekmektedir (Taşdelen, 2015: 23). Dolayısıyla da felsefeyi toplumsal yaşam biçimimize katacak yaratıcı, üretici bir eğitime ihtiyaç vardır (Taşdelen, 2015: 25). Bunun için çocukların konuşmaya başladıktan sonra çevresi ile ilgili sayısız sorular sormasını insanın felsefeye yatkınlığının bir işareti olarak değerlendirilmeli ve bu yatkınlığın geliştirilmesi için çaba sarf edilmelidir (Solak, 1998: 27). Bu bağlamda düşünen/çalışan bir zihninin göstergesi olan soru sormak ailede, eğitimde, toplumda hak ettiği değeri gördüğü vakit felsefi bilinçten söz etmek mümkün olacaktır. $\mathrm{Bu}$ süreçte karşılaşılacak en önemli sorun, felsefi bilinci kazandırmak için kullanılan bazı felsefelerin anlaşılmaz bulunup bunlardan sıkılmaktır. Ancak "anlamadığım şeyi neden inceleyeyim" düșüncesiyle bu teorileri bir kenara atmak doğru bir yaklaşım olmayacaktır. Bu bağlamda bazı felsefelerin toplum için anlamsız olması doğaldır, çünkü onlar o toplumun dinamiklerinden beslenen bir felsefe değildir. Ancak bu tablo karşısındaki tavrımız, anlaşılmaz olanı anlamlandırma çabası ile sonuçlanmalıdır. Aksi takdirde toplum bu felsefelerin en kötülerine karşı savunmasız hale gelecektir (Rand, 2003: 16). Bu da toplumun amaçladığı hedefler doğrultusunda değil bir başkasının amaçları doğrultusunda değişip dönüşmesine neden olacaktır. Bu sebeple toplum, kendi değerleri ile örtüşen bir eğitim anlayışı, bilim ve teknolojiye ait ürünler ortaya koyamayacaktır. Dahası başkalarının egemenliği altına girerek, başkalarının kültürü ile yaşamını şekillendirmek zorunda kalacak olan bu toplumlar, felsefenin ve felsefi bilincin imkânını zora sokacaktır.

\section{Kaynakça}

Akdemir, Abamüslim. (2004). Felsefi Düşünme Ya Da Düşünmeyi Öğrenme, Kâzım Karabekir Eğitim Fakültesi Dergisi, 10, 44-59.

Bakır, Kemal. (2014). Demokratik Eğitim, 3. Baskı. Ankara: Pegem Akademi. 
Brehier, Emile. (1966). Bugünkü Felsefe Konuları (Mehmet Toprak, Çev.), İstanbul: Remzi Kitapevi.

Çelebi, Kâtip. (1993). Mîzânü'l- Hak Fî İhtiyâri'l - Ahak, İstanbul: MEB.

Çevikbaş, S. (2010). Felsefe(Miz) Üzerine Bir Deneme (Türkiye'de Felsefe Nasıl Olanaklıdır?), Atatürk Üniversitesi Sosyal Bilimler Enstitüsü Dergisi, 6(2), 39-48.

Çotuksöken, Betül. (2000). Felsefi Söylem Nedir?, İstanbul: İnkılâp Yayınevi.

Duralı, Ş. Teoman (2009). Felsefe-Bilim Nedir?, 2. Bask1. İstanbul: Dergâh Yayınları.

Feuerbach, Ludwig. (1991). Geleceğin Felsefesinin İlkeleri (Oğuz Özügül, Çev.), İstanbul: Ara Yayıncilık.

Gündoğan, A. Osman. (1993). Filozof ve Felsefe Hakkında, Felsefe Dünyas1, 10, 4045.

Gürsoy, Kenan. (2006). Bir Felsefe Geleneğimiz Var Mı?, İstanbul: Etkileşim Yayınevi.

Gülenç, Kurtuluş. (2015). Frankfurt Okulu, İstanbul: Ayrıntı Yayınları.

Hilav, Selahattin. (2014). Felsefe El Kitabı, 5. Baskı. İstanbul: Yap1 Kredi Yayınları.

Ibanez, Felix Marti. (1998). Felsefe Öyküleri, 2. Baskı. (Hamide Koyukan, Çev.), Ankara: İmge Kitabevi.

İnam, Ahmet. (1993). Çözümlemeci Düşünmenin Felsefedeki Yeri Üstüne, Felsefe Dünyası Dergisi, 10, 2-7.

İnam, Ahmet. (1994). Sicak ve Soğuk Felsefe, Felsefe Dünyası, 14, 6-10.

Marinoff, Lou. (2007). Felsefe Terapisi, 4. Baskı. (Erhan Sökmen, Çev.), İstanbul: Gendaş Kültür.

Öner, Necati. (1999). Felsefe Yolunda Düşünceler, 2. Bask1. Ankara: Akçağ Yayınevi.

Rand, Ayn. (2003). İhtiyacımız Olan Felsefe ( Nejdet Kandemir, Çev.), İstanbul: Plato Film Yayınları.

Russell, Bertrand. (2001). Eğitim Üzerine, 5. Baskı. (Nail Bezel, Çev.), İstanbul: Say Yayınları.

Solak, Adem. (2005). Felsefe Yolunda, Ankara: Hegem\&Bilimadamı Yayınları.

Taşdelen, Vefa. (2015). Felsefe Kültürü, Ankara: Hece Yayınları. 
Timuçin, Afşar. (1991). Güçlü Bir Felsefe Eğitiminin Temel Kuralları Neler Olmalıdır, Felsefe Dünyas1 Dergisi, 1, 27-30.

TÜRKER-KÜYEL, Mübahat. (1986). Bilimin Felsefeye Dayandı̆̆ı Görüşünün Bir Timsali Olarak Galenos, http://dergiler.ankara.edu.tr/dergiler/26/1050/12671.pdf (01.10.2015).

UYGUR, Nermi. (1981). Yaşama Felsefesi, İstanbul: Çağdaş Yayınları.

UYGUR, Nermi. (2001). Felsefenin Çağrısı, 5. Baskı. İstanbul: Yapı Kredi Yayınları.

UYGUR, Nermi. (2012). Türk Felsefesinin Boyutları, 2. Bask1. İstanbul: Yap1 Kredi Yayınları. 